NBER WORKING PAPER SERIES

THE EFFECTS OF COCAINE AND

MARIJUANA USE ON MARRIAGE

AND MARITAL STABILITY

Robert Kaestner

Working Paper No. 5038

NATIONAL BUREAU OF ECONOMIC RESEARCH

1050 Massachusetts Avenue

Cambridge, MA 02138

February 1995

This paper is part of NBER's research program in Health Economics. Any opinions expressed are those of the author and not those of the National Bureau of Economic Research.

(C) 1995 by Robert Kaestner. All rights reserved. Short sections of text, not to exceed two paragraphs, may be quoted without explicit permission provided that full credit, including (C) notice, is given to the source. 


\title{
THE EFFECTS OF COCAINE AND \\ MARIJUANA USE ON MARRIAGE \\ AND MARITAL STABILITY
}

\begin{abstract}
This paper examines the relationship between illicit drug use and marital status. The paper starts with an overview of the relevant economic theory for this problem. Then, using data from the National Longitudinal Survey of Labor Market Experiences, the paper presents both cross sectional and longitudinal estimates of the effect of marijuana and cocaine use on marital status, time until first marriage, and duration of first marriage. The results indicate that in general, drug users are more likely to be unmarried due to a delay in the age at first marriage, and shorter marriage durations. The findings are not uniform, however, and differ according to the gender, race and age of the sample.
\end{abstract}

Robert Kaestner

National Bureau of Economic Research

269 Mercer Street

8th Floor

New York, NY 10003-6687 


\section{Introduction}

The family plays a vital role in our society and is an important economic institution. A substantial amount of our national output is produced in the home, and the family serves as an efficient form of organizing this type of economic activity. One of the most significant and long lasting contributions of the family, is the production and rearing of children. There is a growing public concern regarding the dramatic changes in family structure that have recently occurred. The decline in the prevalence of the traditional family is frequently cited as a potential cause of many of the current problems associated with children, including poor educational outcomes, drug abuse and teenage pregnancy. A statistical portrait of the U.S. clearly illustrates that the nuclear family is no longer the dominant form of living arrangement. Divorce rates have increased while marriage rates have decreased, and these factors have eroded the primacy of the nuclear family (Wojtkiewicz et. al. 1990). ${ }^{1}$

The growth in the number of children that grow up in predominantly single parent households has generated interest in the effect this experience will have on the children's subsequent development. Past research has provided a considerable amount of evidence detailing the consequences of living in a single parent household (Mclanahan and Booth 1989). Previous studies have found that the absence of a spouse (i.e. father) has a negative impact on children's educational achievement, even after controlling for the level of household income. ${ }^{2}$ Furthermore, Mclanahan (1985) and Mclanahan and Bumpass (1988) found that children from one parent families are more likely to experience inferior outcomes later in life, such as an increased incidence of poverty, teenage child bearing, and marital dissolution. Given the adverse consequences on children's development associated with single parent households, there is a natural interest in identifying the factors that adversely affect family formation and dissolution.

One possible factor may be an individual's use of illicit drugs. In cross sectional surveys of 
illicit drug use, there is a significant negative correlation between illicit drug use and marital status; individuals who are married report a significantly lower amount of illicit drug use. Table 1 provides data on marijuana and cocaine use as of 1992 from a recent national survey; the youth cohort of the National Longitudinal Survey of Labor Market Experiences (NLSY) (Center for Human Resources 1994). As can be seen in Table 1, a person who is married is less likely to use cocaine or marijuana than a person who has never been married, or a person who is divorced or separated. Similar findings based on national samples have been reported by Bachman et. al. (1984) and Clayton and Voss (1977). Furthermore, Yamaguchi and Kandel (1987), and Newcomb and Bentler (1987) reported results consistent with those above, using regional samples of young adults.

While drug use may not be the primary cause of the recent trends in family formation and dissolution, it may be a significant contributing factor to these problems. The primary purpose of this paper is to investigate this possibility analytically as well as empirically. The empirical analysis is particularly important, because it focuses on a sample of young adults; a population with a high prevalence rate of illicit drug use, low marriage rates, and high divorce rates. It is exactly this age group that are in the process of making their family related decisions. In addition, the current research addresses several methodological problems that previous studies have ignored. In general, the results indicate that drug users are more likely to be unmarried due to a delay in the age at first marriage, and shorter marriage durations.

\section{Past Research}

The only previous study to have systematically examined the relationship between illicit drug use and marital status is Yamaguchi and Kandel (1987). In that paper, the authors examined the effects of marijuana and other illicit drugs on the timing of marriage and divorce, for a regional sample of young adults between the ages of 24 and 25. Yamaguchi and Kandel (1987) presented 
evidence which indicates that use of marijuana and other illicit drugs delayed entry into marriage for women, but for men, marriage is delayed only for those men who use marijuana. Use of other illicit drugs has no effect on the timing of marriage for men. In addition, the authors find that marijuana use during the marriage led to an increased rate of divorce for both men and women in the sample, although use of other illicit drugs had no effect on the timing of divorce for either gender.

The authors explanation of their findings is based on the concept of social role incompatibility. Yamaguchi and Kandel (1987) viewed drug use as being incompatible with adult social roles such as marriage; therefore those individuals who use drugs delay entry into marriage (i.e., adulthood). Individuals who continue to use drugs while married are more likely to get divorced, since the use of drugs is incompatible with the adult social role of marriage. The explanation offered by Yamaguchi and Kandel (1987) is not sufficient, however, to explain the findings reported in their paper. For example, Yamaguchi and Kandel (1987) found that the effects of drug use on marital status, differed depending on the type of drug (marijuana v. other illicit drugs), which would appear to be inconsistent with their theoretical prediction. If marijuana use is incompatible with adult social roles then the use other illicit drugs, such as heroin and cocaine, should also be incompatible with these roles. In addition, the authors ignore several empirical problems that serve to undermine the validity of their conclusions. ${ }^{3}$

\section{The Economics of Marriage and Drug Use}

From the economists' perspective, there are several reasons why we would expect there to be a systematic relationship between illicit drug use and marital status. The seminal work of Becker $(1973,1974,1981)$, on the economics of marriage and the family, provides the theoretical underpinnings for these expectations. ${ }^{4}$ According to Becker, individuals marry to take advantage of the gains from marriage that result from increased specialization in home production and market work. 
The extent of the division of labor in the household, and ultimately the size of the gains from marriage, are determined by the respective wage rates and productivities in household work of the spouses. Thus, any factor that affects wage rates, home productivity, or the ability to substitute time in household production will affect the potential gains from marriage and the decision to marry. Illicit drug use may affect all three of these attributes.

Illicit drug use is expected to negatively affect an individual's wage and future earnings power. ${ }^{5}$ A lower wage affects the decision to marry since it affects the potential gains from marriage. Becker (1981) shows that the gains from marriage to a woman of a given quality are greatest for low wage men when there is negative assortative mating on the wage. Thus, high wage men will be more likely to remain single or marry later than low wage men. Under these conditions, men who use illicit drugs (i.e., low wage men) would be more likely to marry. The low wage drug users will outbid their higher wage counterparts for the right to marry a woman of particular quality by offering the woman a greater share of the household output. A similar argument applies to women. It should be noted that this result depends on the ceritus paribus condition, and the assumption that there is negative assortative mating on the wage. ${ }^{6}$

Illicit drug use may also be expected to decrease the productivity of the individual within the household. Becker (1981) showed that there is likely to be positive assortative mating on traits that affect non-market productivity, although this result depends on the degree of substitutability between the spouses' non-market time. Assuming positive assortative mating, those individuals with more of a given trait will be most likely to be married. If illicit drug use is positively correlated with traits which affect the types of non-market activities in which spouses' time tend to be complements, then individuals who use illicit drugs will be less likely to be married. This result is due to the proposition that there is positive assortative mating when spouses' time are complementary, and that drug use reduces the amount of the trait that affects non-market productivity. For example, individuals who 
use illicit drugs are expected to be less healthy due to the adverse physical effects of illicit drug use. Consequently, their poor health may make them less efficient in the production of children, an activity in which spouses' non-market time is necessarily complementary. Therefore we would expect drug users to be less likely to be married. Of course the net effect of drug use would depend on a variety of traits associated with drug use. ${ }^{7}$ Illicit drug use may directly decrease the health, intellectual ability, and emotional stability of an individual, all traits that affect non-market productivity.

Finally, the use of illicit drugs can be thought of as a time intensive commodity, since it is reasonable to assume, given the physical effects of illicit drug use, that a substantial amount of leisure time is required to produce the good of interest, say "euphoria" to use the terminology of Stigler and Becker (1977). The nature of the activity, however, prevents the married couple from taking advantage of the household division of labor, since it is not possible to substitute spouse's time in the production of this good. Consequently, the gain from marriage is reduced, and the individual will be less likely to be married.

In a world of perfect information, a summary of the effects of illicit drugs on the potential gains from marriage would be sufficient to predict the effect of illicit drug use on marital status. In a world of imperfect information, however, marital dissolution and remarriage are possible outcomes. Keeley (1977) and Becker et. al. (1977) analyzed the impact of imperfect information on the marriage market. The role of imperfect information is formalized by noting that information about a potential spouse is costly to obtain. Thus, the individual is faced with a tradeoff: continue searching for a better match (i.e., spouse) and incur the cost of the additional search, or accept the current match which is less than the perfect match available in the marriage market. Drug use may affect the person's search behavior or the traits of an individual after marriage. In addition, illicit drug use may also be associated with an increase in the variance of the expected gain from marriage, which could lead to poor matches, and thus marital dissolutions (Becker et. al. 1977). 
The costs of search could be higher for users of illicit drugs if there is a societal stigma attached to drug use. The illicit drug user will be more likely to accept a poor match, since he or she expects the preferences of potential mates to be influenced by societal values. As noted above, a poor match will lead to an increase in the probability of divorce. This point illustrates how the effects of drug use may differ by the type of drug. For example, among recent cohorts the norm is to have experimented with marijuana, but cocaine use is much less prevalent. Therefore, it is more likely that social stigma will affect cocaine use. Illicit drug use may lower the cost of search. however, if the buying of drugs in the market creates an environment where people with like traits (i.e., drug use) can easily meet.

Users of illicit drugs may also be more likely to experience divorce because of an increase in the uncertainty associated with the expected gain from marriage due to their drug use. For example, if we assume that illicit drug use only has an adverse effect on income if a person becomes addicted, the expected income of a person depends on whether the person will become addicted to illicit drugs. If the probability of addiction is characterized by a distribution with a large variance, then the expected income of potential spouses who use drugs will also have a large variance. The large variance of expected income will lead to more marital disruptions (Becker et. al. 1977). There is an increased likelihood that the actual output of the marriage will deviate from the expected marital output. More generally, an individual's behavior subsequent to marriage might be more prone to change, or more difficult to predict, due to the effects of illicit drug use. A harsh example of this is found in Kantor and Strauss (1989), who report that substance abuse is highly correlated with wife abuse. ${ }^{8}$

In summary, economic theory provides several possible explanations for the observed cross sectional relationship between illicit drug use and marital status. Models of the marriage market predict that the effect of illicit drug use on the marriage decision and marital stability tends to be negative, in the sense that illicit drug use tends to decrease the probability of being married, and 
increase the probability of divorce, although this prediction is subject to some qualification.

\section{Data}

The data used in the analysis come from the youth cohort of the National Longitudinal Survey (NLSY), a longitudinal survey of the labor market experiences of young adults (Center for Human Resource Research 1994). The starting year of the survey was 1979 and included an initial sample of approximately 12500 youths aged 14-21 at that time. The survey has been updated each year since 1979 with a broadening array of purposes and questions. The data contain detailed information on a respondent's labor market experience, marital history, family and personal background, and illicit drug use. Central to the purposes of this paper are the questions related to respondents' illicit drug use. In 1988 and 1992 the respondent was asked questions about their lifetime and recent use of marijuana and cocaine. ${ }^{9}$ Thus, the empirical analysis makes use of data primarily from these two years.

The illicit drug use questions are limited in two major respects. First, as is reported by Mensch and (1988), there may be some underreporting of illicit drug use, mostly with regard to cocaine use. The exact nature of the underreporting is not known, but Mensch and (1988) suggested that for the 1984 NLSY data underreporting is more common among relatively light users, compared to heavy users of illicit drugs, and more pronounced among females and minorities. The levels of reported drug use in the 1988 NLSY survey, however, are comparable to those reported in the 1988 National Household Survey (NHS) on Drug Abuse (National Institute on Drug Abuse 1988). The NHS reports a lifetime prevalence of cocaine use of $32.6 \%$ among males, and $21.2 \%$ among females, for a sample of respondents between the ages of 26 and 34. In comparison, respondents in the NLSY who are between the ages of 26 and 32 in 1988, report an unweighted lifetime prevalence of cocaine use of $33.4 \%$ among males, and $22.3 \%$ among females. ${ }^{10}$ The NHS figures would be expected to be higher, since the comparison group from those data are somewhat older, and therefore have a greater 
chance of initiating use. For marijuana use, the NLSY male sample reported a lifetime prevalence of use of $70.0 \%$, compared to $68.1 \%$ for the NHS. The women in the NLSY also reported a greater prevalence of marijuana use, $59.3 \%$ compared to the $56.2 \%$ figure reported in the NHS. These findings raise questions about the extent of underreporting in the NLSY, and particularly, whether there was in fact substantial underreporting as suggested by Mensch and Furthermore, Sickles and Taubman (1991) reported an unpublished study that counters the Mensch and (1988) criticism, and suggests that the self reports of illicit drug use in the NLSY are reliable. Finally, Johnston et. al. (1989) conclude that in the "Monitoring the Future" data, the self-reported drug use is also a valid indicator of true drug use.

The second problem related to the drug use questions, is the absence of longitudinal data and a measure of quantity of use; only the frequency of drug use is measured. Although the frequency of use and quantity of use are expected to be highly correlated, Stein et. al. (1988) presented evidence suggesting that the quantity of illicit drug use is a more significant predictor of social problems than the frequency of drug use. In the NLSY, the frequency of drug use is obtained only for certain time periods: lifetime and past month use as of the 1988 and 1992 interviews. For other periods, the only information obtained about the respondent's illicit drug use was whether or not the respondent had initiated use prior to that period. Table 1 shows the prevalence and distribution of drug use by marital status, gender and race in 1992 .

\section{Empirical Estimates Of the Effect of Drug Use on Marriage and Marital Stability}

The effects of illicit drug use on the marriage market will be examined from three different empirical perspectives. The first analysis examines the relationship between current marital status and past drug use, treating drug use as exogenous. This analysis is primarily descriptive and is intended to answer the following question. Controlling for other factors, is illicit drug use significantly related 
to marital status? The second analysis is similar to the first, but in this case the assumption that marital status does not affect drug use is tested. The purpose of this analysis is to obtain a structural or causal estimate of the effect of drug use on marital status. While it is always difficult to confidently identify a true causal effect, this analysis should address at least one potentially confounding issue, namely the possibility that the estimate obtained in the first analysis is subject to a simultaneity bias. Finally, two longitudinal analyses are implemented: one is an investigation of the effect of being a drug user on the age at first marriage, and the other a study of the effect of past drug use on the time until divorce for those that are married. These two analyses complement the previous ones by providing information as to which aspects of the marriage market are being most affected by drug use, since they look at marriage and divorce separately. Furthermore, these estimates can also be given a causal interpretation since the timing of one measure of drug use and marital changes is known.

\section{A. Current Marital Status - Exogenous Drug Use}

The first analysis examines the relationship between past and current illicit drug use and current marital status. In particular, a multinomial logit model is used to estimate the effect of drug use on the probability of observing a person in one of three marital states: never married, married, or separated/divorced. Results from these analyses will provide preliminary evidence regarding the nature of the relationship between illicit drug use and marital status.

The multinomial logit model is derived from the following simple consumer choice problem. Let utility be denoted by $V_{i j}$, where $i$ indexes the person and $j$ indexes the marital state. The person's utility is expressed as

(1) $V_{i j}=f\left(Z_{i}\right)$, 
where the $Z_{i}$ are characteristics of the individual, including the amount of illicit drug use. The use of individual characteristics, as opposed to the objects of consumer choice, such as consumption and leisure in each marital state, results in a reduced form model (Hoffman and Duncan 1988). The person bases his or her choice on the comparison of utilities across alternative marital states. They choose marital state $\mathrm{j}$ if

(2) $\operatorname{Prob}\left(V_{\mathrm{ij}}>V_{\mathrm{ik}}\right)$ for all $\mathrm{k}=\mathrm{j}$.

If an error term is added to equation (1), and assumed to be an independent and identically distributed random variable with an extreme value (Type 1) distribution, the model can be estimated using the multinomial logit method described by McFadden (1984).

The dependent variable will take on one of three values, indicating that the respondent is either married, divorced/separated or never married. Along with several measures of past and current illicit drug use, a large set of explanatory variables will be included in the model. The set of regressors will consist of personal characteristics of the respondent, family background measures, and geographical specific measures. The respondent's personal characteristics include the following variables, measured at the time of interview: age, race, education, labor market experience, and health status. ${ }^{11}$ Also included the model are personal characteristics measured at either the 1979 or 1980 interview dates; score on the armed forces qualifications test, the desired number of children, and frequency of religious attendance. The family background variables include mother's education, and whether the respondent had a' two parent household at ages 14 and 18 . The area specific measures include region of residence, and the following variables measured at the county level; population density, marriage and divorce rates, percent of population that is female, and the percent of all births to women under 20 years of age. 


\section{Results}

The estimates of the effect of drug use obtained from the multinomial logit models are listed in Tables 2 through 5. A complete set of estimates from two representative models are contained in the appendix. The coefficients in the "married" state are set equal to 0 , and this normalization makes the "married" state the reference group category. Thus, a positive coefficient estimate indicates an increased likelihood of observing an individual in a particular state relative to "married." Separate estimates were obtained by gender, race (black and non-black) and age (27-31 and 32-35) using data from the 1988 and 1992 survey years. The separation of the sample along these lines allows for a preliminary analysis of age and cohort effects. In both 1988 and 1992, there was a group of persons between the ages of 27 and 31 . Thus, separate estimates may identify any (birth) cohort effects among this age group. Furthermore, in 1992, the group of individuals between the ages of 32 and 35 consist primarily of those individuals who were 27 to 31 years of age in 1988 . Differences in the estimates between these two groups may reflect an age effect. For each demographic group, five models were estimated with each model including different measures of drug use. ${ }^{12}$ The range of values for each drug use measure are listed in Tables 2 and 3.

Table 2 contains the results for the non-black male sample. Virtually all of the estimates of the effect of cocaine use on the marital status of non-black males are positive and significant at the .05 level. These results indicate that those non-black males who have used cocaine are more likely than their non-using counterparts to be not married. The estimates also imply that cocaine use has a larger effect on the relative (to being married) odds of being divorced or separated since the estimates in the columns labeled divorce or separated are larger than those in the never married column. Similarly, the estimates of the effect of past year cocaine use are larger than the estimates of lifetime use. The estimates of the effect of marijuana use on the marital status of non-black males are mixed. Estimates of the effect of past year marijuana use are always positive and significant, indicating that 
non-black males who used marijuana in the past year are less likely to be married than their non-using counterparts. The estimates of the effect of lifetime marijuana use show a surprising pattern. Relatively moderate past users are less likely to be married than either heavier users or non-users. This result, however, pertains only to the 1992 estimates. In general, lifetime marijuana use does not appear to significantly affect the marital status of non-black males.

As far as cohort effects, there does not appear to be a systematic difference between the 1988 and 1992 estimates for the group of non-black males between the ages of 27 and 31 . This result is surprising because between the two survey years there was a significant change in sample composition. After the 1990 survey, approximately 20 percent of the non-black sample was dropped, and this group consisted solely of low income individuals. It is also interesting to note that reported drug use declined substantially between the 1988 and 1992 surveys. For example, 46 percent of the non-black males between the ages of 27 and 31 reported some past cocaine use in 1988, while the same figure for 1992 is only 32 percent. Similar declines for the black male sample, however, suggest that the decline in reported drug use is due to other factors besides changes in the sample composition, since black persons were not dropped from the survey. There also doesn't appear to be significant age effects, since the estimates for the sample of non-black males between the ages of 27 and 31 in 1988 are similar to those for the sample of non-black males between the ages of 32 and 35 in 1992.

The results for black males are listed in Table 3. Contrary to the findings for the non-black male sample, the estimates of the effect of drug use on marital status are for the most part not significantly different from zero. Furthermore, the signs associated with the estimates do not indicate a consistent pattern. The insignificance of the drug effect estimates are similar to estimates of the effect of other variables in the model. In general, the model did a poor job explaining or describing the marital choices of black males.

Table 4 lists the estimates of the effect of drug use on the marital status of non-black females. 
The estimates in Table 4 are qualitatively similar to those in Table 2 . Among the non-black sample of females, the estimates of the effect of both lifetime and past year cocaine use are significant and suggest that cocaine users are less likely to be married than otherwise similar non-users. There is one significant exception, however, and that is in reference to past year cocaine use for the sample of nonblack females between the ages of 32 and 35 . For this group, the estimate of the effect of past year cocaine use is insignificant. The effect of current marijuana use on marital status is similar to that of cocaine: users are less likely to be married. One difference between the non-black male and female estimates is that the female estimates associated with marijuana use tend to be larger than those for cocaine use, and lifetime marijuana use is associated with an increase in the relative odds of being divorced or separated.

Unlike the results for black males, several of the estimates of the effect of drug use on marital status of black females are significant, and most are positive. These estimates are listed in Table 5. In particular, current marijuana use, and to a lesser extent, current cocaine use. is associated with an increased likelihood of being never married relative to married.

In summary, it was found that drug use is significantly correlated with marital status for all but one of the demographic groups analyzed in this paper, although the results tended to be stronger for the non-black samples. Thus, the results listed in Tables 2 through 5 provide a definitive answer to the first question posed in this paper. Controlling for other factors, drug users are more likely than non-users to be observed in an unmarried state because of increases in the relative odds of being never married and separated or divorced. The question of whether drug use causes an individual to be in a certain marital state is a question that will be considered in the analyses that follow.

\section{B. Current Marital Status - Endogenous Drug Use}

Economic models of the marriage decision suggest that the optimal consumption bundle changes 
with the marital state (Becker 1981, Manser and Brown 1980). Thus, an empirical investigation of the effects of drug use on marriage and marital stability needs to be concerned about the possible endogeneity of drug use. For example, the positive estimates in Tables 2 through 5 of the effect of drug use on the probability of never being married may be because single persons are more likely to use drugs, and not because drugs cause someone to be single.

In order to address this simultaneity problem, a two equation model was estimated that treats illicit drug use as an endogenous variable. For this model, the three marital states are collapsed into two, married and not married. The model was estimated using a Two Stage Least Squares (2SLS) procedure suggested by Heckman and MaCurdy (1985) for models in which there are dummy endogenous variables. The procedure is similar to the usual 2SLS procedure, except that the standard errors are calculated using White's procedure. Heckman and MaCurdy (1985) show that the resulting parameter estimates and their standard errors are consistent estimates of the population parameters. The structural model may be written for person i as follows:

$$
\mathrm{M}_{\mathrm{i}}=\delta_{\mathrm{D}} \mathrm{D}_{\mathrm{i}}+\mathrm{X}_{\mathrm{Mi}} \beta_{\mathrm{M}}+\varepsilon_{\mathrm{Mi}} \text {, }
$$

$$
\mathrm{D}_{\mathrm{i}}=\delta_{\mathrm{M}} \mathrm{M}_{\mathrm{i}}+\mathrm{X}_{\mathrm{Di}} \beta_{\mathrm{D}}+\varepsilon_{\mathrm{Di}},
$$

where $\mathrm{M}$ is a dummy variable indicating the person is currently married, $\mathrm{D}$ is the level of past drug use, and the $\mathrm{X}$ are vectors of exogenous variables. The exogenous variables included in the marriage equation are the same as those outlined above and include personal characteristics of the respondent, family background measures, and local area specific measures.

The most important aspect related to estimating this model is finding variables to identify the 
two equations. In this analysis, the following variables are used to predict drug use, but not marital status; crime and poverty rates in the county of residence, an index of self-esteem as measured in 1980 , the Rotter locus of control score as measured in 1979, and the number of reported illegal activities during 1980 . Theses instruments do a reasonably good job predicting drug use, particularly the number of illegal activities and county crime rate. F-tests of the overidentification restrictions were carried out for each of the sixty models listed in Tables 2 through 5 . In only 4 cases did the test statistic reject the null hypothesis that the restrictions were valid. ${ }^{13}$

Formal tests of exogeneity were also carried out using the Wu-Hausman test. ${ }^{14}$ In only fourteen out of the sixty cases did the Wu-Hausman test reject the assumption of exogeneity, and half of the rejections occurred among the non-black female sample who were between the ages of 27 and 31. Given the results of the Wu-Hausman test, the structural model is estimated only for the sample of non-black females between the ages of 27 and 31 . In addition to the 2SLS estimates, the estimates of the effect of drug use from a linear probability (OLS) model are also included for comparison purposes. The standard errors associated with the OLS estimates have been calculated using White's method. The same model specifications as those used in Tables 2 through 5 are also used in this analysis. There is only one exception, and that is for models 1 and 3 . Instead of using two dummy variables to represent lifetime drug use, only a measure of relatively heavy use is included. The multicollinearity inherent in the 2SLS procedure makes it difficult to estimate a model that includes a predicted measure of both moderate and heavy use. ${ }^{15}$

The structural estimates of the effect of drug use on marital status are listed in Table 6. First, note that the OLS estimates of the effect of drug use on marital status are consistent with those in Table 4. The negative estimates found in Table 6 imply that drug users are less likely to be married. The only exception to this conclusion is the estimate of the effect of heavy marijuana use which is positive and significant. The 2 SLS estimates of the effect of drug use suggest a similar conclusion, 
although the magnitude of the estimates and the associated standard errors are approximately 5 to 10 times larger than the OLS estimates. The order of magnitude differences in the estimates is expected given the 2SLS methodology. Heavy drug use and past year drug use are infrequent events, and thus there is little variation in these dummy variables. Using a predicted value as an instrument further reduces the variation in these variables, and increases the multicollinearity problem. The result of these circumstances are large estimates and standard errors.

In summary, the endogeneity issue has been explored in detail, and it was not found to significantly alter the general conclusion that drug use tends to reduce the likelihood of being married. While this evidence is not enough to prove the presence of a causal link between drug use and marital status, it does rule out one possible argument against such a conclusion; namely that there is a simultaneity bias.

\section{Longitudinal Results}

In a further attempt to identify the causal nature of the relationship between drug use and marriage, two longitudinal analyses were conducted which examine the probability of changing marital states: never married to married and married to divorced. Since the timing of drug use is known in these analysis, the simultaneity issue previously discussed is not a problem in these analyses. The first longitudinal analysis will examine the determinants of the time until first marriage, for all respondents who turned 18 years old after 1979 , the starting data of the survey. It is assumed that the respondent is not at risk of marriage prior to their eighteenth birthday; less than $3 \%$ of the sample married before their eighteenth birthday. The basic unit of measurement will be months, and several variables will be updated on a monthly basis as they change. The last year of the survey that is used is 1988 , and those respondents who are not married (divorced) at the end of this period will be treated as censored observations. The 1988 date was used because it is the last survey year that information 
about drug use was collected before the NLSY sample was significantly decreased. After 1990 the NLSY dropped approximately 20 percent of the non-black sample. The set of time invariant regressors will consist of many of the same variables used in the cross sectional analysis that measure the respondent's personal characteristics, and the characteristics of their family. The time varying regressors will include the proportion of time since age 18 that the person was at work, the number of dependent children, and an indicator of initiation into use of an illicit drug. ${ }^{16}$

The sample used for the analysis of the duration of the first marriage will consist of all first marriages observed after 1979 , for those respondents who turned 18 years of age after this date. The time invariant explanatory variables used in this analysis include family background measures, the respondent's age and education at the time of marriage, and the spouse's age and education at the time of marriage. Time varying variables include the number of dependent children, the proportion of time the person was working since the start of the marriage, and an indicator of initiation into drug use.

A continuous time, "flexible" proportional hazards model, as specified by Flinn and Heckman (1982), will be used to obtain estimates of the two duration models. The Flinn and Heckman (1982) specification of the conditional hazard function, $\mathrm{h}(\mathrm{t} \mid \mathrm{X}, \phi)$, nests several commonly used hazard models such as the Weibull and Gompertz models, and can be written as follows;

(5) $\ln [\mathrm{h}(\mathrm{t} \mid \mathrm{X}, \phi)]=\mathrm{X}^{\prime}(\mathrm{t}) \mathrm{B}+\mathrm{g}_{1}\left[\left(\mathrm{t}^{\lambda}-1\right) / \lambda\right]+\mathrm{g}_{2}\left[\left(\mathrm{t}^{\mu}-1\right) / \mu\right]+\phi$,

where $\mathrm{X}(\mathrm{t})$ is a $1 \times \mathrm{k}$ vector of regressors, $\mathrm{B}$ is a $\mathrm{k} \times 1$ vector of parameters, and $\phi$ is a scaler measuring unobserved heterogeneity. The $\mathrm{g}_{\mathrm{i}}{ }^{\prime} \mathrm{s}, \lambda$ and $\mu$ are parameters to be estimated, and which measure the duration dependence of the hazard function. Several well known hazard functions can be derived from equation (5) by setting the duration parameters equal to a specific value. The model will be estimated using the CTM statistical software (Yi, Honore and Walker 1987) which incorporates 
the non-parametric maximum likelihood estimator of Heckman and Singer (1984). This estimation strategy make no distributional assumption about the form of the unobserved heterogeneity.

There is one data limitation associated with these analyses. As noted above, the respondents were questioned about their drug use at only a few points in time, and complete retrospective data were not obtained. Thus, the data on illicit drug use is not truly longitudinal, and matching the drug use data with the two dependent variables is problematic. An alternative sampling scheme often employed by researchers (see Yamaguchi and Kandel 1987) is to use only those individuals who were not married (single) at the time of the interview when retrospective data on drug use is available, and estimate the effect of illicit drug use on the remaining duration in the state. This strategy leads to a non-random sample, and is an example of what Lancaster (1990) calls "stock sampling." The consequence of "stock sampling" is that the selected sample will be unrepresentative of the population, and will have an average spell duration greater than that observed in the population. ${ }^{17}$

In order to avoid the problems noted above with regard to "stock sampling," the empirical analysis of this paper uses all of the spells observed in the sample. The disadvantage of this strategy is that the only measure of illicit drug use that can be used to obtain estimates of the drug effect is age of first use. There is no way of knowing if the drug use associated with the other measures of use preceded the marriage or was subsequent to the marriage. This is not a problem with the age of first use. The age of first use can be thought of as indicating that the respondent has chosen to be a user of this drug, and is at risk of using this drug in future periods. In practice the age at first use would be measured as a dummy variable, which would be equal to one in periods after the respondent reported having first used the illicit drug. The disadvantage of this measure of drug use is that cessation of use is not known. Thus, what is actually being measured at any particular time is a mixture of current and past drug users. 


\section{Results}

Table 7 contains estimates of the effect of marijuana and cocaine use on the hazard function for first marriage for those who were never married, and the hazard function for divorce, for those in their first marriage. A full set of results is contained in the appendix for two models. The measure of drug use included in the model is an indicator of any past use. The estimates will be obtained using the model specified by equation (6). A Weibull distribution was used in the case of age at first marriage, and a quadratic log hazard is specified for the duration of first marriage. These functional forms were chosen based on the results of likelihood ratio tests. In addition, each model was estimated separately under one of two assumptions: that the sample is homogenous with respect to unobserved factors, or that the sample is heterogenous with respect to unobserved factors. Estimates of the model under the heterogenous assumption are obtained using the Heckman and Singer (1984) non-parametric maximum likelihood estimator. All but two of the estimates in Table 5 are from a model which assumes a homogenous sample, because empirical tests showed this assumption to be valid. Finally, only the non-black respondents are used in the analysis of duration of first marriage due to data limitations. ${ }^{18}$

The estimates in Table 7 indicate that cocaine use decreases the hazard function for first marriage by 25 percent for non-black males and 30 percent for black males, although the estimate for black males is insignificant. Among females, cocaine use decreases the hazard for first marriage by 21 percent for non-black females. The estimate of the effect of cocaine use on the marriage hazard for black females is not significant. In general, marijuana use does not have a significant effect on the marriage hazard, except for black females in which case the hazard is decreased by 31 percent. A decrease in the marriage hazard implies that past and current drug users tend to delay marriage relative to their non-using counterparts.

Drug use also has a substantial impact on the hazard function for divorce. Cocaine use 
increases this hazard by 25 percent for non-black males and 76 percent for non-black females, although the estimate for the male sample is not significant. The only hazard in which the assumption of homogeneity was rejected was the male divorce hazard. The estimate of the effect of cocaine use from a model that assumed homogeneity was .45 and significant, indicating a 45 percent increase in the divorce hazard. Marijuana use increases the divorce hazard by 74 percent for non-black males and 57 percent for non-black females. Both effects are statistically significant. An increase in the divorce hazard implies that drug users have shorter marital durations.

The conclusions derived from Table 7 are consistent with past findings and suggest that drug users are more likely to delay marriage and have shorter marital durations than non-users, although there were some non-uniformity in the results. Marijuana use does not appear to affect the age at first marriage for most individuals, although the results suggest that continued use does lead to marital disruptions. Use of cocaine results in individuals delaying marriage, and for those that are married, cocaine use leads to shorter marital durations. These estimates provide additional support for a causal argument, since the measure of drug use included in these models is by definition exogenous. The results are less than conclusive, however, because initiation into drug use does not necessarily imply continued use.

\section{Conclusions}

In this paper, the relationship between drug use and marital status has been examined from three different empirical perspectives. The first analysis was concerned with the following question. Controlling for other factors, is drug use systematically related to marital status? The answer to this question was primarily yes. Although an interesting result, this last conclusion does not answer the question of whether drug use causes individuals to alter their behavior toward marriage. The evidence presented in this paper, while not conclusive, does seem to suggest that drug use does in fact influence 
young adults behavior toward marriage. The results from the structural and duration models provide evidence of a causal relationship. Of course, there is always the possibility that some unobserved variable, correlated with both drug use and marital status, has been omitted, thus biasing the results. Future work should address this issue further. The results of this analysis, however, suggest that the reason we observe more drug users in the non-married state is that they tend to delay marriage, and are more likely to divorce because of their drug use than non-users.

The results in this paper have important public policy implications. These results suggest that the pattern of family formation and dissolution is being significantly affected by drug use. As noted in the introduction, delayed marriage and increased divorce will tend to increase the number of households headed by single parents. In addition, drug use is altering the age at which child rearing takes place. It is these considerations, plus others, that make the relationship between drug use and marital status interesting. This paper is the first paper to systematically present evidence on the question. It will be of interest to see whether future researchers arrive at similar conclusions. 


\section{Endnotes}

I would like to thank Chris Flinn, Ted Joyce and Robert Moffit for their valuable suggestions. Ewa Wojas provided excellent research assistance. Financial support for this research came from grant \#DA08596-01 from the National Institute on Drug Abuse.

1. In $1970,71 \%$ of all households contained a married couple, but as of 1989 this figure had been reduced to 57\% (Wetzel 1990). Among households with children in 1970, 89\% had two parents, whereas in 1988 the same figure had dropped to $77 \%$ (Wetzel 1990). Furthermore, Mclanahan and Bumpass (1988) estimated that $50 \%$ of all children will spend some time growing up in a single parent home.

2. Studies by Krein and Beller (1988), and Mclanahan (1985) find that, compared with children from a two parent household, children from single parent households have obtained less education by the time they are young adults. Datcher-Loury (1988) and Wolfe (1982) report similar findings related to the cognitive development of younger children from single parent households. For recent studies that find no effect of single parent households on child education see Blau and Grossberg (1992) and Hanushek (1992).

3. For example, Kandel and Yamaguchi (1985) ignore the impact of unobserved heterogeneity, and assume a constant (i.e., exponential) hazard rate of exit from a marital state.

4. Alternatively, the household bargaining models of Manser and Brown (1980) and McElroy and Horney (1981) could be used as a theoretical framework. In these papers, the gain from marriage is due to the exclusive availability of a household produced public good derived from the marriage. The fact that the household good is produced in the home suggests that the gain from marriage is still dependent on the division of labor in the household, as in Becker (1981).

5. Recent work by Kaestner (1991,1994), Gill and Michaels (1992) and Register and Williams (1992) on the effect of illicit drug use on wages has found an insignificant and even positive effect of drug use on the wage. These studies examined a relatively young sample, however, and from the point of view of the marriage market, it is the permanent wage that will be important not the current wage. These studies examined the effect of illicit drug use only on the current wage.

6. In related work, Lam (1988) shows that if there is joint consumption of a household public good, the optimal outcome in the marriage market may result in positive assortative mating on the wage.

7. The important issue from a policy perspective is whether illicit drug use causes individuals to have certain traits, not just that illicit drug use is correlated with individual traits. Illicit drug use is also expected to be correlated with poor health for reasons that are unrelated to the direct effect of drug use. Becker and Murphy (1988) suggest that drug users will have a higher rate of time preference, and Grossman (1972) shows that individual's with a higher rate of time preference will be more likely to be in poor health. Thus, drug use is correlated with poor health, but does not cause poor health. 
8. Another good example of this phenomena might be related to the number of desired children. If illicit drug use increases the variance of fertility, maybe due to inefficient use of contraception, the desired and actual number of children will tend to differ.

9. The NLSY also included questions about a respondent's drug use in 1984, but the empirical analysis focuses on the later years of the survey when more of the sample has made their marital decisions.

10. The NHS figures would be expected to be higher, since the comparison group from that data are somewhat older, and therefore have a greater chance of initiating use. In addition, the NLS oversamples blacks, and respondents from the south, two groups that have reported to lower levels of illicit drug use (Kozel and Adams 1985). Thus, if anything we would expect greater use of illicit drugs in the NHS sample. Of course since the age groups in the two surveys do not overlap perfectly, there could be a cohort (i.e., birth year) effect that is confounding the estimates, although this would be expected to be quite small.

11. In addition to the models reported in the text, estimates were obtained for models that excluded education, labor force experience and health. These reduced form estimates of the effect of drug use were quite similar to those reported in the text.

12. Several other models were estimated that included different specifications of the drug use variables. The results reported in the text are an accurate representation of the full range of estimates. In addition, estimates were obtained for a younger cohort between the ages of 23 and 26 using the 1984 and 1988 surveys. Results for this sample were similar to those reported.

13. Basman's F-Test was used to test the overidentifying restrictions. For these tests, the heteroscedasticity was ignored, but the large p-values that resulted strongly suggest that using this test statistic is adequate for this sample. In most cases the p-values were greater than .3 .

14. The Wu-Hausman test amount to running a regression with the actual and predicted drug use variables in the model. Exogeneity is rejected if the coefficient associated with the predicted use is significant. For these tests the standard errors were calculated using White's procedure.

15. The multicollinearity problems associated with the 2SLS procedure are illustrated by model 5 in Table 4. The inflation of the standard errors between the OLS and 2SLS estimates is substantial.

16. Education could not be included among the time varying regressors due to data limitations. The data are not detailed enough to identify the date of degree and periods when the respondent was in school over the entire period under analysis. The respondents score on the armed forces qualifications test is included and is significantly correlated with last observed education level.

17. An added complication in the current case is that the probability of having a longer spell is expected to depend on illicit drug use. Heckman and Singer (1984) show that this "stock sampling" will lead to biased estimates of the population parameters and incorrect inferences, even if the selection criteria is unrelated to illicit drug use. The dependency of the selection criteria on illicit drug use creates a simultaneity issue, in addition to the "length biased" sampling problem. Solutions to these problems have yet to be proposed in the literature. 
18. Due to the small number of divorces observed among the black sample, 32 for men and 55 for women, an analysis of the duration of marriage was not feasible. 


\section{References}

Bachman, Jerald., O'Malley, Peter. and Johnston, Lloyd. 1984. "Drug Use Among Young Adults: The Impact of Role Status and Social Environment." Journal of Personality and Social Psychology 47:629-645.

Becker, Gary S. 1973. "A Theory of Marriage: Part I." Journal of Political Economy 81:813-846.

Becker, Gary S. 1974. "A Theory of Marriage: Part II." Journal of Political Economy 82:S11-S26.

Becker, Gary. 1981 A Treatise on the Family. Cambridge, Mass.: Harvard University Press.

Becker, Gary S., and Murphy, Kevin M. 1988. "A Theory of Rational Addiction." Journal of Political Economy 96:675-700.

Becker, Gary S., Landes, Elisabeth M., and Michael, Robert T. 1977. "An Economic Analysis of Marital Instability." Journal of Political Economy 85:1141-1187.

Blau, Francine D. and Adam J. Grossberg. "Maternal Labor Supply and Children's Cognitive Development." Review of Economics and Statistics, .

Center for Human Resources. 1994. NLS Handbook, Columbus Ohio: Ohio State University Center for Human Resources.

Clayton, R.R., and Voss, H.L. 1977. "Shaking Up: Cohabitation in the 1970's." Journal of Marriage and the Family 39:273-283.

Datcher-Loury, Linda. 1989. "Family Background and School Achievement Among Low Income Blacks." The Journal of Human Resources 24:528-544.

Flinn, C. and J. Heckman. 1982. "New Methods for Analyzing Structural Models of Labor Force Dynamics." Journal of Econometrics 18:115-168.

Gill, Andrew M., and Michaels, Robert J. 1992. "Does Drug Use Lower Wages?" Industrial and Labor Relations Review 45:93-105.

Grossman, Michael. 1972. "On the Concept of Health Capital and the Demand for Health." Journal of Political Economy 80:223-255.

Hanushek, Eric A. "The Trade-off Between Child Quantity and Quality." Journal of Political Economy, Vol 100, No 1, February 1992: pp. 84-117.

Heaton, Tim B. 1990. "Marital Stability Throughout the Child-Rearing Years." Demography 27:5563. 
Heckman, James, and Thomas MaCurdy. 1985. "A Simultaneous Linear Probability Model." Canadian Journal of Economics 18:27-37.

Heckman, James J. and Burton Singer. 1984. "Econometric Duration Analysis." Journal of Econometrics 24:63-132.

Hoffman, Saul D., and Duncan, Greg J. 1988. "Multinomial and Conditional Logit Discrete Choice Models in Demography." Demography 25:415-427.

Johnston, Lloyd D.; O'Malley, Patrick M.; and Bachman, Jerald D. 1989. Illicit Drug Use, Smoking. and Drinking by America's High School Students, College Students, and Young Adults, 19751988. DHHS Publication No. (ADM) 89-1638. Washington, D.C.: U.S. Government Printing Office.

Kaestner, Robert. 1991. "The Effect of Illicit Drug Use on the Wages of Young Adults." Journal of Labor Economics 9:332-354.

Kaestner, Robert. 1994. "New Estimates of the Effect of Marijuana and Cocaine Use on Wages: Accounting for Unobserved Person Specific Effects." Industrial and Labor Relations Review, 47:454-470.

Kaestner, Robert. 1994. "The Effect of Illicit Drug Use on the Labor Supply of Young Adults." Journal of Human Resources 29:123-136.

Kantor, Glenda K., and Strauss, Murray A. 1989. "Substance Abuse as a Precipitant of Wife Abuse Victimizations." The American Journal of Drug and Alcohol Abuse 15:173-189.

Keeley, Michael C. 1977. "The Economics of Family Formation. " Economic Inquiry 15:238-250.

Kozel, Nicholas and Adams, Edgar. 1985. eds. Cocaine Use in America: Epidemiological and Clinical Perspectives. Washington, D.C.: U.S. Department of Health and Human Services.

Krein, Sheila Fitzgerald and Andrea H. Beller. 1988. "Educational Attainment of Children from Single-Parent Families: Differences by Exposure, Gender, and Race." Demography 25:221-234.

Lam, David. 1988. "Marriage Markets and Assortative Mating with Household Public Goods." Journal of Human Resources 23:462-487.

Lancaster, Tony. 1990. The Econometric Analysis of Transition Data. Cambridge: Cambridge University Press.

McElroy, Marjorie, and Horney, Mary. 1981. "Nash-Bargained Household Decisions: Toward a Generalization of the Theory of Demand." International Economic Review 49:333-349. 
McFadden, Daniel L. 1984. "Econometric Analysis of Qualitative Response Models." in Handbook of Econometrics Vol 2, edited by Z. Grilliches and M.D. Intriligator. New York: Elsevier, pp. $1395-1457$.

McLanahan, Sara. 1985. "Family Structure and the Reproduction of Poverty. " American Journal of Sociology 90:873-901.

McLanahan, Sara and Booth, Kenneth. 1989. "Mother Only Families: Problems, Prospects, and Politics." Journal of Marriage and the Family 5:557-580.

McLanahan, Sara and Larry Bumpass. 1988. "Intergenerational Consequences of Family Disruption." American Journal of Sociology 94:130-152.

Manser, Marilyn, and Brown, Murray. 1980. "Marriage and Household Decision Making: A Bargaining Analysis." International Economic Review 21:31-44.

Mensch, Barbara S., and , Denise B. 1988. "Underreporting of Substance Use in a National Longitudinal Youth Cohort." Public Opinion Quarterly 52:100-124.

National Institute on Drug Abuse. 1988. National Household Survey on Drug Abuse. Rockville, MD.: U.S. Department of Health and Human Services.

Newcomb, Michael D., and Bentler, Peter M. 1987. "Changes in Drug Use from HS to Young Adulthood: Effects of Living Arrangement and Current Life Pursuit." Journal of Applied Developmental Psychology 8:221-246.

Register, Charles A., and Williams, Donald R. 1992. "Labor Market Effects of Marijuana and Cocaine Use Among Young Males." Industrial and Labor Relations Review 45:106-123.

Sickles, Robin, and Taubman, Paul. 1991. "Who Uses Illegal Drugs." American Economic Review $81: 248-251$.

Stein, Judith A.; Newcomb, Michael D.; and Bentler, P.M. 1988. "Structure of Drug Use Behaviors and Consequences Among Young Adults: Multitrait - Multimethod Assessment of Frequency, Quantity, Work Site, and Problem Substance Use." Journal of Applied Psychology 73:595605 .

Stigler, George, and Becker, Gary. 1977. "De Gustibus Non Est Disputandum." American Economic Review 67:76-90.

Wetzel, James R. 1990. "American Families: 75 Years of Change." Monthly Labor Review (March):4-13.

Wojtkiewicz, Roger A., McLanahan, Sara S., and Garfinkel, Irwin. 1990. "The Growth of Families Headed by Women: 1950-1980." Demography 27:19-30. 
Wolfe, John R. 1982. "The Impact of Family Resources on Childhood IQ." The Journal of Human Resources 17:213-235.

Yamaguchi, K. and , Kandel, Denise. 1987. "On the Resolution of Role Incompatibility: A Life History Analysis of Family Roles and Marijuana Use." American Journal of Sociology 92:836-878.

Yi, Kei-Mu,Honore, Bo, and Walker, James. 1987. "A Program for the Estimation and Testing of Continuous Time Multi-State Multi-Spell Models." Unpublished manuscript University of Chicago. 
Table 1

Percent of Respondents with Reported Drug Use

by Gender, Age and Marital Status in 1992

\begin{tabular}{|c|c|c|c|c|c|c|c|}
\hline \multirow[b]{2}{*}{ Sample } & \multirow[b]{2}{*}{ Drug } & \multicolumn{3}{|c|}{ Males } & \multicolumn{3}{|c|}{ Females } \\
\hline & & $\begin{array}{c}\text { Never } \\
\text { Married }\end{array}$ & Married & Divorced & $\begin{array}{c}\text { Never } \\
\text { Married }\end{array}$ & Married & Divorced \\
\hline \multirow[t]{5}{*}{$\begin{array}{l}\text { Non-Black } \\
\text { Age 27-31 }\end{array}$} & $\begin{array}{c}\text { Lifetime } \\
\text { Cocaine Use }\end{array}$ & $40 \%$ & $27 \%$ & $39 \%$ & $28 \%$ & $20 \%$ & $32 \%$ \\
\hline & $\begin{array}{l}\text { Past Year } \\
\text { Cocaine Use }\end{array}$ & $8 \%$ & $3 \%$ & $12 \%$ & $3 \%$ & $2 \%$ & $7 \%$ \\
\hline & $\begin{array}{c}\text { Lifetime } \\
\text { Marijuana Use }\end{array}$ & $68 \%$ & $63 \%$ & $71 \%$ & $56 \%$ & $54 \%$ & $69 \%$ \\
\hline & $\begin{array}{c}\text { Past Year } \\
\text { Marijuana Use }\end{array}$ & $25 \%$ & $12 \%$ & $32 \%$ & $13 \%$ & $8 \%$ & $20 \%$ \\
\hline & $\begin{array}{c}\text { Observations } \\
(\%)\end{array}$ & $\begin{array}{l}412 \\
(33)\end{array}$ & $\begin{array}{l}725 \\
(58) \\
\end{array}$ & $\begin{array}{l}122 \\
(10)\end{array}$ & $\begin{array}{l}268 \\
(20) \\
\end{array}$ & $\begin{array}{l}857 \\
(63) \\
\end{array}$ & $\begin{array}{l}225 \\
(17) \\
\end{array}$ \\
\hline \multirow[t]{5}{*}{$\begin{array}{l}\text { Non-Black } \\
\text { Age } 32-35\end{array}$} & $\begin{array}{l}\text { Lifetime } \\
\text { Cocaine Use }\end{array}$ & $42 \%$ & $25 \%$ & $51 \%$ & $29 \%$ & $19 \%$ & $32 \%$ \\
\hline & $\begin{array}{l}\text { Past Year } \\
\text { Cocaine Use }\end{array}$ & $10 \%$ & $3 \%$ & $10 \%$ & $2 \%$ & $2 \%$ & $4 \%$ \\
\hline & $\begin{array}{c}\text { Lifetime } \\
\text { Marijuana Use }\end{array}$ & $62 \%$ & $62 \%$ & $78 \%$ & $51 \%$ & $53 \%$ & $70 \%$ \\
\hline & $\begin{array}{c}\text { Past Year } \\
\text { Marijuana Use }\end{array}$ & $23 \%$ & $10 \%$ & $24 \%$ & $15 \%$ & $6 \%$ & $13 \%$ \\
\hline & $\begin{array}{l}\text { Observations } \\
(\%)\end{array}$ & $\begin{array}{r}146 \\
(18) \\
\end{array}$ & $\begin{array}{l}548 \\
(68) \\
\end{array}$ & $\begin{array}{l}113 \\
(14)\end{array}$ & $\begin{array}{l}119 \\
(13)\end{array}$ & $\begin{array}{l}640 \\
(69)\end{array}$ & $\begin{array}{r}173 \\
(19)\end{array}$ \\
\hline \multirow[t]{5}{*}{$\begin{array}{c}\text { Black } \\
\text { Age 27-31 }\end{array}$} & $\begin{array}{c}\text { Lifetime } \\
\text { Cocaine Use }\end{array}$ & $24 \%$ & $17 \%$ & $27 \%$ & $12 \%$ & $7 \%$ & $10 \%$ \\
\hline & $\begin{array}{c}\text { Past Year } \\
\text { Cocaine Use }\end{array}$ & $7 \%$ & $4 \%$ & $11 \%$ & $4 \%$ & $2 \%$ & $3 \%$ \\
\hline & $\begin{array}{c}\text { Lifetime } \\
\text { Marijuana Use }\end{array}$ & $56 \%$ & $60 \%$ & $63 \%$ & $42 \%$ & $34 \%$ & $35 \%$ \\
\hline & $\begin{array}{c}\text { Past Year } \\
\text { Marijuana Use }\end{array}$ & $19 \%$ & $11 \%$ & $21 \%$ & $10 \%$ & $4 \%$ & $7 \%$ \\
\hline & $\begin{array}{c}\text { Observations } \\
(\%)\end{array}$ & $\begin{array}{l}260 \\
(52)\end{array}$ & $\begin{array}{l}173 \\
(35)\end{array}$ & $\begin{array}{c}63 \\
(13) \\
\end{array}$ & $\begin{array}{r}284 \\
(48) \\
\end{array}$ & $\begin{array}{l}194 \\
(33) \\
\end{array}$ & $\begin{array}{r}116 \\
(20) \\
\end{array}$ \\
\hline \multirow[t]{5}{*}{$\begin{array}{c}\text { Black } \\
\text { Age } 32-35\end{array}$} & $\begin{array}{c}\text { Lifetime } \\
\text { Cocaine Use }\end{array}$ & $26 \%$ & $22 \%$ & $25 \%$ & $13 \%$ & $7 \%$ & $12 \%$ \\
\hline & $\begin{array}{l}\text { Past Year } \\
\text { Cocaine Use }\end{array}$ & $13 \%$ & $3 \%$ & $5 \%$ & $2 \%$ & $1 \%$ & $3 \%$ \\
\hline & $\begin{array}{c}\text { Lifetime } \\
\text { Marijuana Use }\end{array}$ & $57 \%$ & $48 \%$ & $51 \%$ & $44 \%$ & $39 \%$ & $43 \%$ \\
\hline & $\begin{array}{l}\text { Past Year } \\
\text { Marijuana Use }\end{array}$ & $16 \%$ & $9 \%$ & $11 \%$ & $14 \%$ & $5 \%$ & $7 \%$ \\
\hline & $\begin{array}{c}\text { Observations } \\
\text { (\%) }\end{array}$ & $\begin{array}{l}127 \\
(42)\end{array}$ & $\begin{array}{l}120 \\
(39)\end{array}$ & $\begin{array}{c}57 \\
(19)\end{array}$ & $\begin{array}{l}157 \\
(41)\end{array}$ & $\begin{array}{l}129 \\
(34)\end{array}$ & $\begin{array}{l}99 \\
(26)\end{array}$ \\
\hline
\end{tabular}

Notes: Non-black includes Hispanic and other racial groups besides blacks. 
Table 2

\section{Parameter Estimates of the Effect of Illicit Drug Use \\ On Marital status at Time of Interview \\ (standard errors in parentheses)}

\begin{tabular}{|c|c|c|c|c|c|c|}
\hline \multirow[t]{2}{*}{$\begin{array}{l}\text { Sample / } \\
\text { Drug Type }\end{array}$} & \multicolumn{2}{|c|}{$\begin{array}{c}1988 \\
\text { Ageв } 27-31\end{array}$} & \multicolumn{2}{|c|}{$\begin{array}{c}1992 \\
\text { Ages } 27-31\end{array}$} & \multicolumn{2}{|c|}{$\begin{array}{c}1992 \\
\text { Ages } 32-35\end{array}$} \\
\hline & $\begin{array}{l}\text { Never } \\
\text { Married }\end{array}$ & $\begin{array}{l}\text { Divorce } \\
\text { Sep. }\end{array}$ & $\begin{array}{l}\text { Never } \\
\text { Married }\end{array}$ & $\begin{array}{l}\text { Divorce } \\
\text { Sep. }\end{array}$ & $\begin{array}{l}\text { Never } \\
\text { Married }\end{array}$ & $\begin{array}{c}\text { Divorce } \\
\text { sep. }\end{array}$ \\
\hline $\begin{array}{c}\text { I) Lifetime Cocaine } \\
(1-9 \text { times })\end{array}$ & $\begin{array}{l}0.154 \\
(0.105)\end{array}$ & $\begin{array}{l}0.266 \\
(0.137)\end{array}$ & $\begin{array}{c}0.705 \\
(0.202)\end{array}$ & $\begin{array}{l}0.872 \\
(0.226)\end{array}$ & $\begin{array}{l}0.682 \\
(0.311)\end{array}$ & $\begin{array}{l}1.252 \\
(0.321)\end{array}$ \\
\hline $\begin{array}{l}\text { Lifetime Cocaine } \\
\text { (10 or more times) }\end{array}$ & $\begin{array}{c}0.767 \\
(0.177)\end{array}$ & $\begin{array}{c}1.072 \\
(0.223)\end{array}$ & $\begin{array}{c}0.515 \\
(0.170)\end{array}$ & $\begin{array}{l}0.456 \\
(0.268)\end{array}$ & $\begin{array}{l}0.871 \\
(0.251)\end{array}$ & $\begin{array}{l}0.937 \\
(0.277)\end{array}$ \\
\hline $\begin{array}{l}2 \text { Past Year Cocaine } \\
(0=\text { no, } 1=\text { yes })\end{array}$ & $\begin{array}{l}0.903 \\
(0.193)\end{array}$ & $\begin{array}{l}1.004 \\
(0.236)\end{array}$ & $\begin{array}{c}1.116 \\
(0.312)\end{array}$ & $\begin{array}{l}1.493 \\
(0.387)\end{array}$ & $\begin{array}{l}1.093 \\
(0.396)\end{array}$ & $\begin{array}{l}1.139 \\
(0.434)\end{array}$ \\
\hline $\begin{array}{c}\text { 3) Lifetime Marijuana } \\
(1-49 \text { times })\end{array}$ & $\begin{array}{l}0.023 \\
(0.161)\end{array}$ & $\begin{array}{l}0.069 \\
(0.240)\end{array}$ & $\begin{array}{l}0.247 \\
(0.154)\end{array}$ & $\begin{array}{l}0.537 \\
(0.246)\end{array}$ & $\begin{array}{l}0.225 \\
(0.232)\end{array}$ & $\begin{array}{l}0.951 \\
(0.281)\end{array}$ \\
\hline $\begin{array}{l}\text { Lifetime Marijuana } \\
\text { (50 or more times) }\end{array}$ & $\begin{array}{r}0.213 \\
(0.170)\end{array}$ & $\begin{array}{l}0.686 \\
(0.236)\end{array}$ & $\begin{array}{l}-0.008 \\
(0.191)\end{array}$ & $\begin{array}{l}0.134 \\
(0.307)\end{array}$ & $\begin{array}{l}-0.585 \\
(0.338)\end{array}$ & $\begin{array}{l}0.045 \\
(0.386)\end{array}$ \\
\hline $\begin{array}{l}\text { \& Past Year Marijuana } \\
(0=\text { no, } 1=\text { yes })\end{array}$ & $\begin{array}{r}0.486 \\
(0.145)\end{array}$ & $\begin{array}{l}0.840 \\
(0.123)\end{array}$ & $\begin{array}{c}0.855 \\
(0.172)\end{array}$ & $\begin{array}{l}1.206 \\
(0.240)\end{array}$ & $\begin{array}{l}1.114 \\
(0.271)\end{array}$ & $\begin{array}{l}0.939 \\
(0.294)\end{array}$ \\
\hline $\begin{array}{l}\text { 5) Past Year Marijuana } \\
(0=\text { no, } 1=\text { yea })\end{array}$ & $\begin{array}{l}0.237 \\
(0.163)\end{array}$ & $\begin{array}{l}0.636 \\
(0.202)\end{array}$ & $\begin{array}{r}0.733 \\
(0.181)\end{array}$ & $\begin{array}{l}1.035 \\
(0.254)\end{array}$ & $\begin{array}{r}0.981 \\
(0.288)\end{array}$ & $\begin{array}{l}0.783 \\
(0.310)\end{array}$ \\
\hline $\begin{array}{c}\text { Past Year cocaine } \\
(0=\text { no }, 1=\text { yea })\end{array}$ & $\begin{array}{l}0.765 \\
(0.214)\end{array}$ & $\begin{array}{l}0.657 \\
(0.259)\end{array}$ & $\begin{array}{l}0.702 \\
(0.328)\end{array}$ & $\begin{array}{l}0.941 \\
(0.408)\end{array}$ & $\begin{array}{l}0.617 \\
10.424\end{array}$ & $\begin{array}{l}0.778 \\
(0.459)\end{array}$ \\
\hline $\begin{array}{l}\text { Ooservations in Column } \\
\text { Total Observations }\end{array}$ & $\begin{array}{r}457 \\
1478 \\
\end{array}$ & 195 & $\begin{array}{r}412 \\
1259 \\
\end{array}$ & 122 & $\begin{array}{l}146 \\
807\end{array}$ & 113 \\
\hline
\end{tabular}

iotes:

$\therefore$ The non-black sample includes Hispanic and other racial groups besides blacks. 
Table 3

Parameter Estimates of the Effect of Illicit Drug Use

On Marital Status at Time of Interview

(standard errors in parentheses)

\begin{tabular}{|c|c|c|c|c|c|c|}
\hline $\begin{array}{l}\text { Sample / } \\
\text { Drug Type }\end{array}$ & \multicolumn{2}{|c|}{$\begin{array}{c}1988 \\
\text { Ages } 27-31 \\
\end{array}$} & \multicolumn{2}{|c|}{$\begin{array}{c}1992 \\
\text { Ages } 27-31 \\
\end{array}$} & \multicolumn{2}{|c|}{$\begin{array}{c}1992 \\
\text { Ages } 32-35 \\
\end{array}$} \\
\hline Black Malos & $\begin{array}{c}\text { Never } \\
\text { Married }\end{array}$ & $\begin{array}{c}\text { Divorce } \\
\text { Sep. }\end{array}$ & $\begin{array}{c}\text { Never } \\
\text { Married }\end{array}$ & $\begin{array}{c}\text { Divorce } \\
\text { Sep. }\end{array}$ & $\begin{array}{l}\text { Never } \\
\text { Married }\end{array}$ & $\begin{array}{c}\text { Divorce } \\
\text { sep. }\end{array}$ \\
\hline $\begin{array}{l}\text { 1) Lifetime Cocaine } \\
\text { (1-9 times })\end{array}$ & $\begin{array}{l}0.252 \\
(0.213)\end{array}$ & $\begin{array}{l}0.621 \\
(0.269)\end{array}$ & $\begin{array}{r}0.366 \\
(0.518)\end{array}$ & $\begin{array}{r}0.029 \\
(0.710)\end{array}$ & $\begin{array}{l}-0.123 \\
(0.907)\end{array}$ & $\begin{array}{c}0.150 \\
(1.058)\end{array}$ \\
\hline $\begin{array}{l}\text { Lifetime Cocaine } \\
\text { (10 or more times) }\end{array}$ & $\begin{array}{c}0.743 \\
(0.379)\end{array}$ & $\begin{array}{c}0.011 \\
(0.633)\end{array}$ & $\begin{array}{c}0.216 \\
(0.328)\end{array}$ & $\begin{array}{c}0.387 \\
(0.439)\end{array}$ & $\begin{array}{r}0.005 \\
(0.405)\end{array}$ & $\begin{array}{l}0.050 \\
(0.486)\end{array}$ \\
\hline $\begin{array}{l}\text { 2) Past Year Cocaine } \\
(0=\text { no, } 1=\text { yes })\end{array}$ & $\begin{array}{l}0.780 \\
(0.380)\end{array}$ & $\begin{array}{c}0.548 \\
(0.515)\end{array}$ & $\begin{array}{l}0.595 \\
(0.566)\end{array}$ & $\begin{array}{c}0.971 \\
(0.654)\end{array}$ & $\begin{array}{l}1.132 \\
(0.652)\end{array}$ & $\begin{array}{r}0.270 \\
(0.866)\end{array}$ \\
\hline $\begin{array}{l}\text { 3) Lifetime Marijuana } \\
(1-49 \text { times })\end{array}$ & $\begin{array}{c}0.351 \\
(0.250)\end{array}$ & $\begin{array}{c}0.413 \\
(0.371)\end{array}$ & $\begin{array}{l}-0.361 \\
(0.264)\end{array}$ & $\begin{array}{l}-0.014 \\
(0.381)\end{array}$ & $\begin{array}{c}0.300 \\
(0.354)\end{array}$ & $\begin{array}{l}0.125 \\
(0.425)\end{array}$ \\
\hline Lifetime Marijuana & -0.195 & -0.270 & -0.229 & 0.006 & 0.251 & -0.252 \\
\hline (50 or more times) & $(0.297)$ & $(0.465)$ & $(0.300)$ & $(0.444)$ & $(0.409)$ & $(0.522)$ \\
\hline $\begin{array}{l}\text { 4) Past Year Marijuana } \\
(0=\text { no, } 1=\text { yes })\end{array}$ & $\begin{array}{c}0.227 \\
(0.247)\end{array}$ & $\begin{array}{l}-0.277 \\
(0.381)\end{array}$ & $\begin{array}{l}0.383 \\
10.331\end{array}$ & $\begin{array}{c}0.471 \\
(0.434\rangle\end{array}$ & $\begin{array}{c}0.396 \\
(0.463)\end{array}$ & $\begin{array}{c}0.103 \\
(0.594)\end{array}$ \\
\hline $\begin{array}{l}\text { 5) Past Year Marijuana } \\
(0=\text { no, } 1=\text { yes })\end{array}$ & $\begin{array}{l}-0.218 \\
(0.271)\end{array}$ & $\begin{array}{l}-0.540 \\
(0.433)\end{array}$ & $\begin{array}{l}0.322 \\
(0.339)\end{array}$ & $\begin{array}{c}0.327 \\
(0.452)\end{array}$ & $\begin{array}{c}0.068 \\
(0.511)\end{array}$ & $\begin{array}{l}0.030 \\
(0.622)\end{array}$ \\
\hline $\begin{array}{c}\text { Past Year Cocaine } \\
(0=\text { no, } 1=\text { yes })\end{array}$ & $\begin{array}{c}0.274 \\
(0.214)\end{array}$ & $\begin{array}{c}0.878 \\
(0.580)\end{array}$ & $\begin{array}{l}0.476 \\
(0.581)\end{array}$ & $\begin{array}{c}0.850 \\
(0.677)\end{array}$ & $\begin{array}{r}1.096 \\
(0.704)\end{array}$ & $\begin{array}{r}0.250 \\
(0.908)\end{array}$ \\
\hline $\begin{array}{l}\text { Observations in Column } \\
\text { Total Observations }\end{array}$ & $\begin{array}{l}285 \\
5: 7\end{array}$ & 63 & $\begin{array}{l}260 \\
496 \\
\end{array}$ & 63 & $\begin{array}{l}127 \\
304\end{array}$ & 57 \\
\hline
\end{tabular}


Table 4

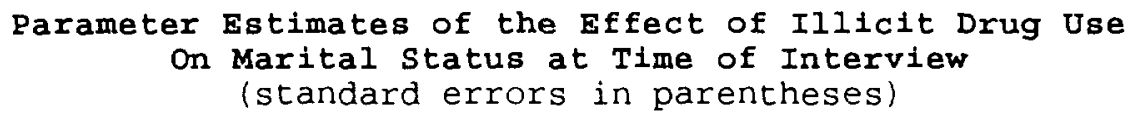

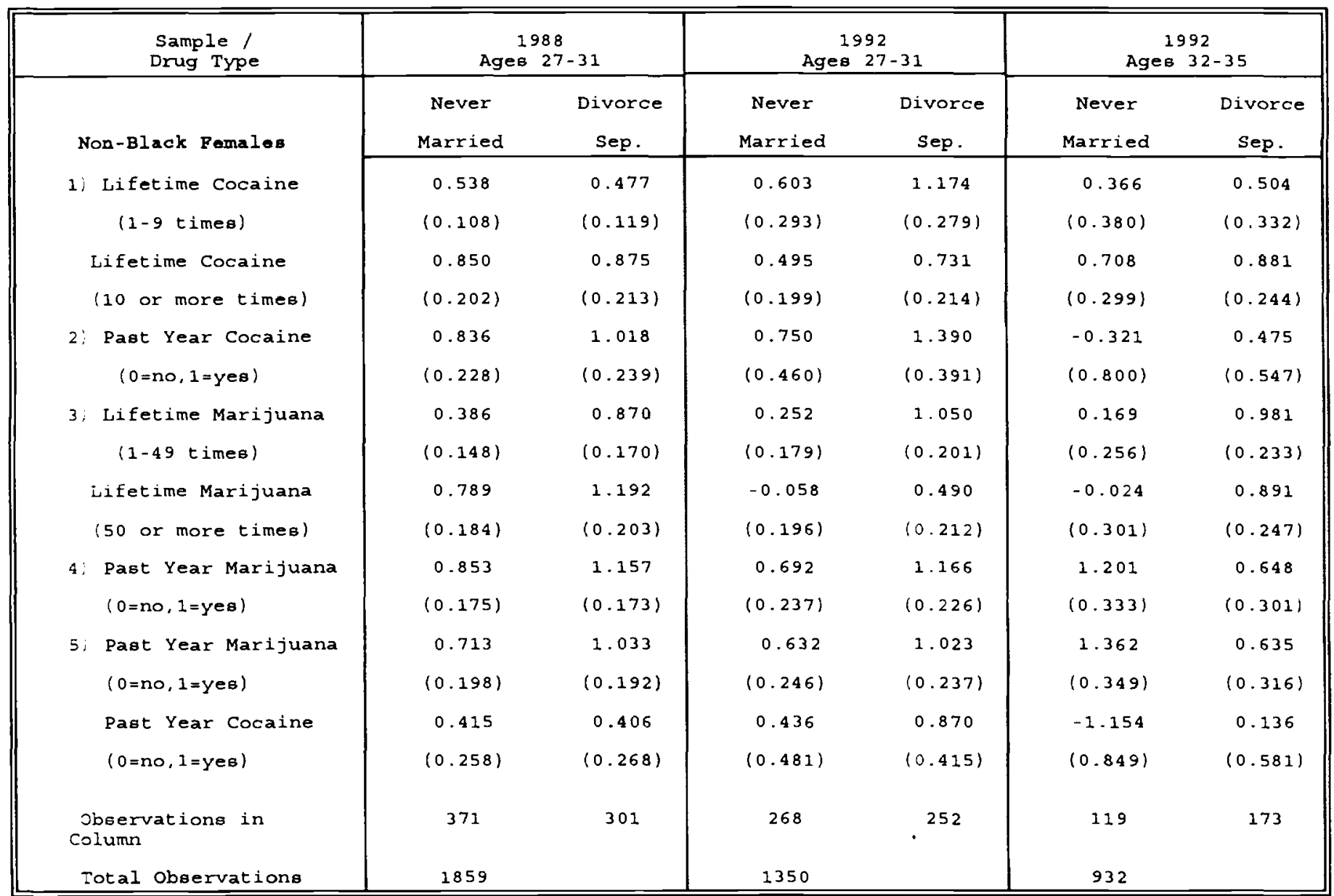

Notes:

1) The non-black sample iccludes both white and hispanic respondents. 
Table 5

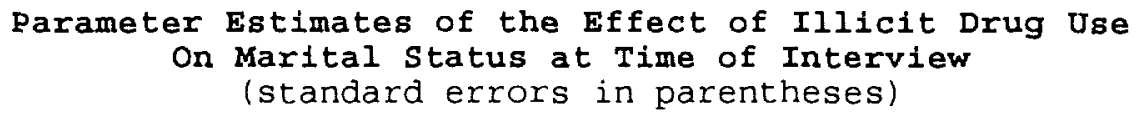

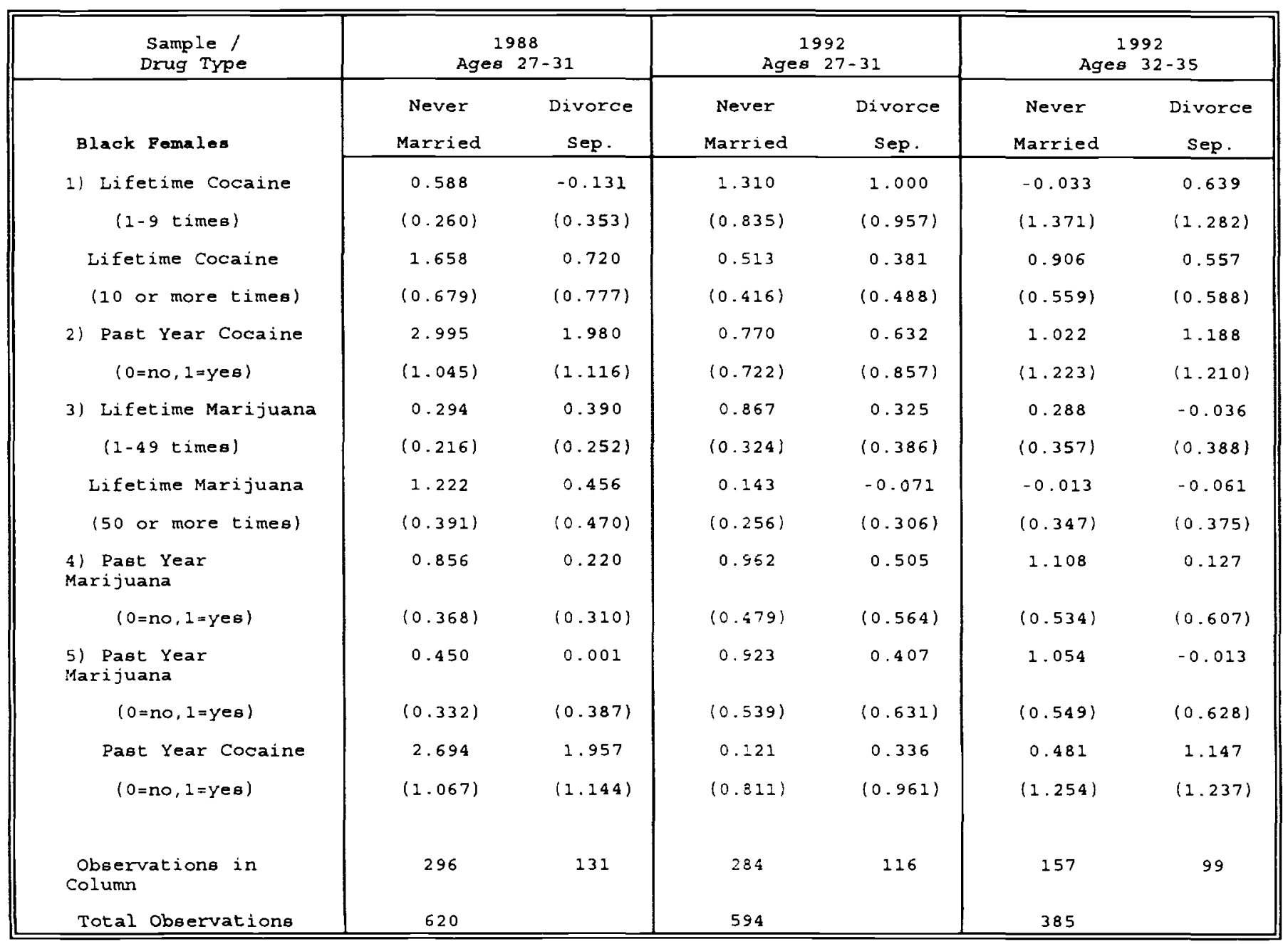


Table 6

Parameter Estimates of the Effect of Illicit Drug Use on the Probability of Being Married at Time of Interview (standard errors in parentheses)

\begin{tabular}{|c|c|c|c|c|}
\hline $\begin{array}{l}\text { Sample ' } \\
\text { Drug Type }\end{array}$ & \multicolumn{2}{|c|}{$\begin{array}{c}1988 \\
\text { Ages } 27-31 \\
\end{array}$} & \multicolumn{2}{|c|}{$\begin{array}{c}1992 \\
\text { Ages } 27-31 \\
\end{array}$} \\
\hline Non-Black Females & OLS & TSLS & OLS & TSLS \\
\hline $\begin{array}{l}\text { 1) Heavy Cocaine Use } \\
\text { (10 or more times) }\end{array}$ & $\begin{array}{l}-0.162 \\
(0.038)\end{array}$ & $\begin{array}{l}-1.751 \\
(0.676)\end{array}$ & $\begin{array}{l}-0.110 \\
(0.036)\end{array}$ & $\begin{array}{l}-0.588 \\
(0.260)\end{array}$ \\
\hline $\begin{array}{l}\text { 2) Past Year Cocaine } \\
(0=\text { no, } 1=\text { yes })\end{array}$ & $\begin{array}{l}-0.215 \\
(0.046)\end{array}$ & $\begin{array}{l}-2.500 \\
(1.001)\end{array}$ & $\begin{array}{l}-0.265 \\
(0.082)\end{array}$ & $\begin{array}{l}-2.814 \\
(1.192)\end{array}$ \\
\hline $\begin{array}{l}\text { 3) Heavy Marijuana Use } \\
\text { (50 or more times) }\end{array}$ & $\begin{array}{l}-0.136 \\
(0.030)\end{array}$ & $\begin{array}{l}-0.744 \\
(0.171)\end{array}$ & $\begin{array}{l}0.023 \\
(0.030)\end{array}$ & $\begin{array}{l}0.770 \\
(0.435)\end{array}$ \\
\hline $\begin{array}{l}\text { 4) Past Year Marijuana } \\
(0=\text { no, } 1 \text { =yes })\end{array}$ & $\begin{array}{l}-0.236 \\
(0.033)\end{array}$ & $\begin{array}{l}-1.250 \\
(0.329)\end{array}$ & $\begin{array}{l}-0.213 \\
(0.044)\end{array}$ & $\begin{array}{l}-0.815 \\
(0.403)\end{array}$ \\
\hline $\begin{array}{l}\text { 5) Past Year Cocaine } \\
(0=\text { no, } 1=\text { yes })\end{array}$ & $\begin{array}{l}-0.090 \\
(0.052)\end{array}$ & $\begin{array}{l}-1.519 \\
(1.710)\end{array}$ & $\begin{array}{l}-0.155 \\
(0.087)\end{array}$ & $\begin{array}{l}-3.620 \\
(2.309)\end{array}$ \\
\hline $\begin{array}{l}\text { Past Year Marijuana } \\
(0=\text { no, } 1=\text { yes })\end{array}$ & $\begin{array}{l}-0.207 \\
(0.037)\end{array}$ & $\begin{array}{l}-0.545 \\
(0.850)\end{array}$ & $\begin{array}{l}-0.188 \\
(0.046)\end{array}$ & $\begin{array}{r}0.433 \\
(0.953)\end{array}$ \\
\hline Observations & 1859 & & 1350 & \\
\hline
\end{tabular}

Notes:

1) The non-black sample includes Hispanic and other racial groups besides blacks. 
Table 7

Parameter Estimates of the Effect of Illicit Drug Use

On the Hazard Function of Marriage and Divorce

(standard errors in parentheses)

\begin{tabular}{|c|c|c|c|c|c|c|}
\hline \multirow[b]{2}{*}{ Drug } & \multicolumn{2}{|c|}{ Non-Black Males } & \multirow{2}{*}{$\begin{array}{c}\text { Black } \\
\text { Males } \\
\text { Marriage } \\
\text { Hazard }\end{array}$} & \multicolumn{2}{|c|}{ Non-Black Females } & \multirow{2}{*}{$\begin{array}{c}\text { Black } \\
\text { Females } \\
\text { Marriag } \\
\text { e } \\
\text { Hazard }\end{array}$} \\
\hline & $\begin{array}{c}\text { Marriage } \\
\text { Hazard }\end{array}$ & $\begin{array}{l}\text { Divorce } \\
\text { Hazard }\end{array}$ & & $\begin{array}{c}\text { Marriag } \\
\mathrm{e} \\
\text { Hazard }\end{array}$ & $\begin{array}{c}\text { Divorc } \\
e \\
\text { Hazard }\end{array}$ & \\
\hline \multirow[t]{2}{*}{ Cocaine } & -.245 & .254 & -.303 & -.213 & .761 & -.110 \\
\hline & $(.083)$ & $(.267)$ & $(.192)$ & $(.087)$ & $(.173)$ & $(.250)$ \\
\hline \multirow[t]{2}{*}{ Marijuana } & .051 & .741 & -.223 & .017 & .571 & -.313 \\
\hline & $(.088)$ & $(.334)$ & $(.171)$ & $(.073)$ & $(.184)$ & $(.141)$ \\
\hline Observations & 1526 & 697 & 749 & 1404 & 844 & 787 \\
\hline Censored & 785 & 555 & 572 & 518 & 655 & 567 \\
\hline
\end{tabular}


Appendix Table 1

Parameter Estimates of Multinomial Logit Model of Marital status

Non-Black Males Aged 27-31 1988 Non-Black Females Aged 32-35 1992 (Table 2)

(Table 4)

Never Married Divorced Never Married Divorced

\begin{tabular}{|c|c|c|c|c|c|c|c|c|}
\hline Variable & Coeff. & $\begin{array}{l}\text { Std. } \\
\text { Error }\end{array}$ & Coeff & $\begin{array}{l}\text { std. } \\
\text { Error }\end{array}$ & Coeff & $\begin{array}{l}\text { Std. } \\
\text { Error }\end{array}$ & Coeff. & $\begin{array}{l}\text { Std. } \\
\text { Error }\end{array}$ \\
\hline Constant & -14.286 & 34510 & 3535 & 44.960 & -332.100 & 138300 & -198030 & 113300 \\
\hline Age & 1.159 & 2.353 & -0.751 & 3.062 & 19.159 & 8.207 & 11.277 & 6.704 \\
\hline Age Squared & -0.022 & 0.040 & 0.014 & 0.522 & -0.285 & 0.122 & -0.164 & 0.099 \\
\hline Hispanic & 0.345 & 0.191 & 0.270 & 0.248 & -0.017 & 0.320 & 0.232 & 0.264 \\
\hline AFQT & -0.029 & 0.018 & 0.004 & 0.024 & -0.041 & 0.027 & 0.033 & 0.026 \\
\hline AFQT squared/100 & 0.016 & 0.014 & -0.003 & 0.018 & -0.018 & 0.020 & -0.030 & 0.020 \\
\hline Experience & -0.246 & 0.125 & -0.014 & 0.164 & -0.004 & 0.007 & 0.001 & 0.006 \\
\hline Experience Sq./100 & 0.045 & 0.804 & -1.107 & 1.052 & 0.008 & 0.004 & 0.012 & 0.034 \\
\hline High School & 0.685 & 0.242 & -0.395 & 0.249 & -0.244 & 0.456 & -0.717 & 0.336 \\
\hline Some College & 1.040 & 0.287 & -0.860 & 0.343 & -0.067 & 0.519 & -0.979 & 0.390 \\
\hline Bachelors & 1.212 & 0.319 & -1.600 & 0.464 & 0.345 & 0.561 & -1.362 & 0.489 \\
\hline Masters & 0.645 & 0.369 & -1.727 & 0.545 & 0.658 & 0.590 & -1.132 & 0.547 \\
\hline Health status & 0.448 & 0.305 & 0.512 & 0.361 & 0.210 & 0.486 & 0.011 & 0.399 \\
\hline Freq. of Religious & -0.038 & 0.041 & -0.135 & 0.059 & -0.072 & 0.068 & -0.119 & 0.060 \\
\hline Two Parents Age 18 & 0.406 & 0.169 & -0.008 & 0.202 & 0.784 & 0.317 & -0.230 & 0.223 \\
\hline Two Parents Age 14 & -0.463 & 0.212 & -0.418 & 0.282 & -0.692 & 0.365 & 0.115 & 0.287 \\
\hline Mother's Education & 0.011 & 0.024 & 0.006 & 0.033 & 0.001 & 0.042 & 0.017 & 0.035 \\
\hline Missing Mother's Ed. & -0.057 & 0.389 & 0.017 & 0.466 & 0.897 & 0.641 & 0.483 & 0.556 \\
\hline Population Density & 0.169 & 0.102 & 0.092 & 0.144 & 0.115 & 0.245 & 0.235 & 0.216 \\
\hline Percent Female & 0.030 & 0.064 & 0.110 & 0.087 & 0.211 & 0.114 & 0.046 & 0.090 \\
\hline Divorce Rate & -0.001 & 0.004 & 0.009 & 0.006 & 0.004 & 0.008 & 0.008 & 0.006 \\
\hline Marriage Rate & -0.001 & 0.002 & -0.002 & 0.002 & -0.004 & 0.005 & -0.001 & 0.001 \\
\hline Pct. Births $<20$ & -0.008 & 0.013 & 0.001 & 0.016 & 0.011 & 0.023 & 0.007 & 0.019 \\
\hline North East & -0.032 & 0.237 & -0.285 & 0.339 & -0.472 & 0.441 & -0.166 & 0.385 \\
\hline North Central & -0.142 & 0.212 & -0.010 & 0.288 & -0.846 & 0.400 & 0.052 & 0.307 \\
\hline South & -0.087 & 0.202 & 0.258 & 0.257 & -0.183 & 0.343 & -0.062 & 0.278 \\
\hline Cocaine $1-9$ times & 0.155 & 0.105 & 0.266 & 0.137 & 0.366 & 0.381 & 0.504 & 0.332 \\
\hline Cocaine $10+$ times & 0.767 & 0.177 & 1.072 & 0.223 & 0.708 & 0.299 & 0.881 & 0.244 \\
\hline $\begin{array}{l}\text { Log-Likelihood } \\
\text { Chi-Squared }\end{array}$ & $\begin{array}{r}-1257.2 \\
309.5\end{array}$ & & & & $\begin{array}{c}-702.46 \\
148.7\end{array}$ & & & \\
\hline
\end{tabular}


Appendix Table 2

Parameter Estimates From Hazard Models Non-Black Sample

\begin{tabular}{|c|c|c|c|c|}
\hline & Male & es & Femal & es \\
\hline & Divorce & Hazard & Marriage & Hazard \\
\hline Variable & Coeff. & $\begin{array}{l}\text { Std. } \\
\text { Error }\end{array}$ & Coeff. & $\begin{array}{l}\text { std. } \\
\text { Error }\end{array}$ \\
\hline 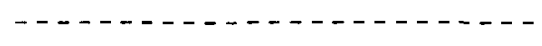 & $----\cdots--$ & ------ & $---\cdots--1$ & ----- \\
\hline Constant & 5.577 & 1.847 & 1.233 & 0.254 \\
\hline Gamma one & 6.497 & 1.303 & 0.140 & 0.034 \\
\hline Gamma two & 0.656 & 0.140 & & \\
\hline Hispanic & -0.249 & 0.368 & -0.118 & 0.100 \\
\hline Expected Age of Marriage & & & & \\
\hline Exp. Age of Marriage $<24$ & & & -0.330 & 0.099 \\
\hline Exp. Age of Marriage $<29$ & & & -0.565 & 0.115 \\
\hline Exp. Age of marriage $<35$ & & & -0.699 & 0.240 \\
\hline Never Expect to Marry & & & -0.359 & 0.277 \\
\hline Desired Num. of Child $<3$ & & & -0.092 & 0.146 \\
\hline $\begin{array}{l}\text { Desired Num. of Child > } 2 \\
\text { Traditional Role }\end{array}$ & -0.672 & 0.247 & -0.209 & 0.150 \\
\hline No Religious Affiliation & 0.944 & 0.359 & -0.057 & 0.134 \\
\hline Baptist & 1.039 & 0.341 & 0.191 & 0.092 \\
\hline Catholic & -0.196 & 0.327 & -0.249 & 0.089 \\
\hline Two Parents Age 14 & -0.220 & 0.315 & 0.170 & 0.091 \\
\hline Mother's Education & 0.419 & 0.519 & -0.338 & 0.125 \\
\hline Missing Mother's Ed. & -0.279 & 0.723 & -0.612 & 0.218 \\
\hline Number of Children & -0.122 & 0.017 & -0.195 & 0.083 \\
\hline Has worked 75-100용 & -0.191 & 0.321 & 0.108 & 0.095 \\
\hline Has worked 50-75\% & 0.244 & 0.365 & -0.064 & 0.116 \\
\hline Has worked 25-50\% & 0.226 & 0.412 & -0.275 & 0.153 \\
\hline Cocaine User & 0.254 & 0.267 & -0.213 & 0.086 \\
\hline $\begin{array}{l}\text { AFQT - Average score } \\
\text { AFQT - High Score }\end{array}$ & & & $\begin{array}{r}0.003 \\
-0.282\end{array}$ & $\begin{array}{l}0.121 \\
0.141\end{array}$ \\
\hline Education & -0.224 & 0.078 & & \\
\hline Age at Marriage & 0.153 & 0.077 & & \\
\hline Spouse's Age at Marriage & -0.447 & 0.463 & & \\
\hline Missing Spouse's Age & 1.904 & 1.692 & & \\
\hline Spouse's Education & -0.153 & 0.099 & & \\
\hline Missing Spouse's Educ. & -0.205 & 0.166 & & \\
\hline Factor Loading & 4.155 & 0.463 & & \\
\hline Log Likelihood & 127.551 & & 776.438 & \\
\hline
\end{tabular}

Notes:1) Percentage of time worked since age 18 in the marriage hazard model, and percentage of time worked since start of marriage for divorce hazard model. 